\title{
HOE WORD DIE SKRIF UITGELE IN DIE PREDIKING?
}

\author{
DS. F. G. J. LOOTS
}

Hierdie studie wil geensins op volledigheid aanspraak maak nie, nog minder wil dit pretendeer om 'n logiese, sistematiese samehang navore te roep. Inteendeel, skrywer hiervan wil slegs enkele pennestrepe trek en poog om gedagtes deur verskeie geleerdes op hierdie gebied uitgespreek en neergeskryf, onder oë te neem en sodoende ' $n$ antwoord te probeer vind op die onderhawige onderwerp en vraag: hoe word die Skrif uitgelê in die prediking. As die ontsaglike literatuurlys oor hierdie betrokke onderwerp nagegaan word, kan daar twee afleidings gemaak word, enersyds dat die hemeneutiek 'n baie belangrike onderwerp is, andersyds dat daar heelwat uiteenlopende gedagterigtings daaroor bestaan. In hierdie studie gaan ons enkele woordomskrywings doen, enkele historiese feite neerpen, verskillende metodes in Skrifuitleg kortliks behandel, die aandag wy aan homiletiese eksegese en enkele algemene opmerkings oor die onderhawige onderwerp blootlê.

\section{ENKELE WOORDOMSKRYWINGS}

\section{a) Skrif en prediking.}

„Die verkondiging van die lewende Woord is worsteling óm die sinvolheid, die verstaanbaarheid en die dinamiek van dis evangelieboodskap in die konkrete hede waarin die mens lewe. Hierdie instelling verteenwoordig nie 'n nuwe insig in die wese van die verkondiging nie. Reeds vir byna 2000 jaar het die lewende Woord in die prediking telkeens die konkrete hede binnegegaan en daardeur gestalte gekry in al die lewensverbande van die tyd. Die vuur van die dinamiese en apostolêre roeping is in hierdie tyd nooit heeltemal uitgedoof nie. Die kerk van die lewende Woord van die lewende Heer het telkens weer in 'n nuwe ,historiese' oomblik en in 'n nuwe situasie 'n nuwe insig gekry op sy diens aan Jesus Christus in die konkrete hede van die menslike bestaan. Ecclesia reformata semper reformanda".')

Met bostaande in gedagte kan ons tereg vra of die verkondiging nog iets te sê het vir die mens van ons dag, anders gestel, of die mens van ons dag, hom steeds betrokke voel by die Woord wat uitgelê, verkondig, duidelik gemaak word. 'n Feit wat nie weggeredeneer kan en mag word nie, is dat die verwardheid en gejaagdheid, die byna koorsagtige vordering op wetenskaplike en teologiese gebied die mens ,bedriegd' laat voel. Dit is juis in hierdie tyd wat die verkondigde Woord steeds gebring word.

1) Müller B.A. „Die lewende Woord aan die mens van die hede,” p 15. 
Die verkondiging vind steeds in die ruimte van die hede plaas. Daarom mag die prediking nie maar 'n bondgenoot soek tussen al die wetenskaplike en tegnologiese strukture ten einde iewers 'n helpende rand te vind nie. Die hele arbeid van die kerk en van die prediking en die hele opbou en wese van die preek moet vanuit die lewende Woord gedirigeer word. ${ }^{2}$ )

Dit bring ons meteens by die innige verbondenheid en gebondenheid tussen Skrif en prediking. Hieroor kan opgemerk word dat daar reeds van die vroegste tye af 'n baie nou samehang tussen Skriflesing en prediking bestaan het. Wat die Bybelse getuienisse betref, noem ons slegs Luk. 24:14-37; Hand. 8:26-40, Hand. 17:2, 3. In al hierdie gevalle - daar is nog meer gevalle in die Bybel - word daar van die Skrif af begin om die Woord uit te lê, om die evangelie te verkondig. Let ons maar net op die geskiedenis van die kamerling (Hand. 8:26-40) dan bemerk ons dat Filippus, nadat hy te wete gekom het dat die kamerling nie verstaan wat hy lees nie, sy mond geopen het „en van hierdie Skrif af begin en die evangelie van Jesus aan hom verkondig."

Ons stel dit dus onomwonde dat daar geen regte, ware prediking kan geskied as dit nie Skrifgebonde is nie. Die prediking is die gepreekte 'Woord van God. De praesentia Christi en die werking van die Heilige Gees is 'n absolute vereiste vir ware prediking. Die testimonium Spiritus Sancti word deur die kerk bely ten opsigte van die Skrif, maar ook ten opsigte van die vertolking daarvan in die prediking. Dit moet 'n gebonde ver. tolking wees, 'n verklaring in die rigting van die inhoud van die Skrif, in die rigting van Jesus Christus. ${ }^{3}$ )

\section{b) Eksegese en hermeneutiek.}

Tereg kan gevra word hoe daar tot Skrifgebonde prediking gekom word, tot prediking wat waarlik dien as 'n verklaring en uiteesetting van God se bedoeling in die skrif.

Meteens het ons aangeland by die speerpunt van die teologiese werksaamheid naamlik die eksegese. Voordat ons enigsins verder gaan, wil ons die woordomskrywing aanhaal soos deur prof. S. P. J. J. van Rensburg'): Die eksegese is die deel van die wetenskap (Ou en Nuwe Testament) wat met alle beskikbare middels probeer om duidelik te maak wat 'n skrywer bedoel het wat hy gespreek en geskryf het. In die teologiese wetenskap neem die eksegese 'n sentrale plek in. Dit hou sig besig met die verklaring van die Skrifte wat in die Christelike kanon opgeneem is.

2) Müller B.A. a.w., p. 15.

3) Barth K., K.D. 1, 2 p. 807 ev.

t) Van Rensburg S. P. J. J. Diktaatlesings eksegese 1965. 
As in aanmerking geneem word dat prediking die tot spreke - bring van ' $n$ bepaalde teks of perikoop is, ' $n$ tot - spreke - bring aan 'n bepaalde gemeente in 'n bepaalde situasie, kan tereg gevra word hoe dit kan gebeur dat 'n bepaalde teks of perikoop oor soveel eeue heen nog tot 'n gemeente van ons dag, tot 'n enkeling in eie nood kan spreek.

Dit bring ons by die hermeneutiek. Die woord hermēneua vind ons onder andere in 1 Kor. 12:10, waar dit bloot beteken die ,uitlê' of ,vertolking van tale.' In 1 Kor. 14:26 het hermēneua die betekenis om die gawe van uitlegging van glossolalie te hê. So tref ons dit aan dat 1 Kor. 14:28 hermēneutēs vir die eerste keer aangetref in Gen. 42:23, dit is waar Josef sy broers ontmoet. Hier tref ons hermēneutēs aan in die betekenis van ,tolk'. Hermeneutiek kan bestempel word as die ,oorbring in 'n ander taal' (met sy wyere betekenis) maar ook kan dit gebruik word in die sin van uitlê, vertolk, verklaar. Opsommenderwys kan gestel word dat eksegese die werksaamheid van die uitlegging van die Heilige Skrif is, terwyl die hermeneutiek die wetenskap, die teorie van die eksegese is. ${ }^{5}$ ) Hermeneutiek sê dan vir ons volgens watter reēls die uilegging van die Skrif moet plaasvind.

Prof. van Rensburgf) merk op dat daar tot 'n regte verklaring van die Skrif gekom kan word as die verklaarder hom wend tot die oorspronklike teks en allereers vra na die letterlike betekenis van die teks. Om die letterlike betekenis van die teks te kan vasstel, moet die teoloog begin om filoloog te wees: wat wil die woorde sê, wat die hele sin, wat is die taalkundige verhoudinge waarmee rekening gehou word in die verklaring.

Bybelse hermeneutiek het dus te make met die Heilige Skrif as Woord van God op 'n besondere en eie wyse. Die reëls wat hier geld sal in die Skrif gesoek moet word. Hermeneutiek wil die wetenskaplike weg aandui wat gevolg moet word om die inhoud van die Woord en woordverband, sin en sinsverband, perikoop, boek, boekversameling en Bybel so te verneem, te verstaan en te interpreteer dat my interpretasie so noukeurig moontlik die bedoeling van die Bybelse getuienis sal weergse in die eietydse taal en gedagtewêreld van hom wat ,hoor' en ,luister'. „Nu is het de bedoeling en de taak der Hermeneutisk, bepaalde richtlijnen aan te geven om geschriften en vooral zulke, welke door taal, tijd en plaats en geestesgestcldheid ver van ons afstaan, zoo te doen verstaan, dat in de eerste plaats hun oorspronklijke zin zoo goed mogelijk tot zijn recht komt." ")

5) Van Rensburg S. P. J. J. aangehaal.

6) Van Rensburg S. P. J. J. aangehaal.

7) Bleeker L. H. K. „Hermeneutiek van het Oude Testament,” p. 3. 
Met die bogenoemde woordomskrywings in gedagte haal ons prof. de $\mathrm{Wet}^{8}$ ) aan: „Prediking moet altyd 'n sinvolle spreketot-mense wees. Sinvol kan 'n preek alleen wees wanneer dit 'n bepaalde Bybelteks of perikoop ooreenkomstig die werklike bedoeling van die skrywer daarvan in die konkrete situasie van 'n gemeente wat in erediens vergader is, tot spreke bring. Dit wil sê, 'n preek is in Bybelse s.n alleen dan sinvol wanneer dit mense met 'n teks aanspreek, tot geloof roep en vir die diens van God opeis. Die konsekutiewe uitgangspunt vir die bepaling van die vorm van die prediking is geleë in die feit dat die prediking spreke - tot - mense is. Prediking kan alleen sinvol wees as dit tuiskom by die adres waaraan dit gerig is. ' $n$ Preek is alleen dan preek wanneer dit daarin slaag om die boodskap in die teks vervat, verhelderend aan die gemeente oor te dra. Die preek is ' $n$ aaneengeskakelde toespraak wat daarom in 'n reeks goed geordende volsinne 'n opsetlike uiting van die gedagtes in 'n teks of perikoop vervat, wil oordra aan 'n gemeente."

\section{ENKELE HISTORIESE OPMERKINGS.}

Onnodig om te sê dat dit haas onmoontlik is om die hele veld van die verlede te dek. Ons gaan nie verder as om slegs 'n paar bakens aan te toon nie. Terloops kan gemeld word dat ons in die volgende paragrawe nie soseer op die hermeneutiese gang sal let nie, as wel hoedat die prediking gedurende sekere tydperke tot sy reg gekom het en ook hoedat dit met tye verskraal en afgetakel is tot bloot stigtelike praatjies.

\section{a) Reformasie.}

Die Hervorming van die $16 \mathrm{e}$ eeu was nie alleen 'n terugkeer tot die Heilige Skrif in die algemeen nie, maar dit het ook die kerk in sy belydenis en liturgie, in Woorddiens en pastorale sorg tot die Woord van God teruggevoer. Die ,predilidienst" wat in die Middeleeue afgetakel is, is daardeur herstel. Die prediking het in die Reformasie ' $n$ sterk aksent ontvang, omdat dit die middel was om die waarheid van die Skrif uit te lê en te verdedig teenoor die dwalinge van Rome. Daardeur het die Hervormers die volk van hulle dae bereik en hulle ore geopen vir die onsuiwere leer van die pousdom. Algaande het die predikamp in die Lutherse en Gereformeerde kerke 'n saak van die grootste gewig geword.

Dit was Luther gewees wat "het Evangelie van de dag" as basis vir sy prediking geneem het. Die preek was vir hom die verkondiging van God se Woord. Die vorm van die prcek het, gemeet aan die streng homiletiese reëls van ons dag, veel te wense oorgelaat. Sy spreke kan tipeer word as praktiese Bybelverklaringe waarin die onderrigtende gedeelte 'n vername plek

8) De Wet J. I. Diktaatlesings 1966. 
ingeneem het. Dit was egter Luther wat die prediking uit sy verval gered het en weer op Skriftuurlike hoogte gebring het. Dit was Luther wat sterk klem gelê het op die tale. „Die tale is die skede waarin die swaard van die Gees steek", aldus Luther.

Calvyn het die prediking, nog sterker as Luther, in Skriftuurlike bane gelei. Hy het in sy Institusie dieselfde gedagte omtrent die prioriteit van die Woorddiens ontwikkel. Hy het met talle argumente betoog dat die suiwere prediking van die evangelie noodsaaklik is vir die opbou van die gemeente. Hy het beweer dat as die Woord van God verkondig word, die prediker, die dienaar van die Woord, rype vrugte op sy arbeid sal sien. As daar in die erediens tot ons gepreek word, spreek God tot ons en as Hy tot ons spreek, sal ons hoor en gehoorsaam.

Wat die vorm van die prediking betref, het Calvyn sterk aangedring op harmonie van explicatio en applicatio. Beide is noodsaaklik vir die prediking. Explicatio en applicatio moet 'n eenheid vorm sodat die toepassing nie as 'n stertjie aan die verklaring gevoeg word nie.

„In de preken van Calvijn vinden we echter nog niet die dispositie van thema en verdeling, die we bij de latere Gereformeerde homileten vinden." ${ }^{\prime}$ ) Sy uiteensetting was egter Skrifverklaring in die beste sin van die woord en hy het ooit uit die oog verloor nie dat die Woord en sy prediking een van die media gratiae is waardeur die Heilige Gees die weldade van Christus ons deelagtig maak. Die groot raamwerk het vir die Hervormers gedraai om die boodskap en die verkondiging daarvan. Die Heilige Skrif was vir hulle die lewende aansprekende Woord van God wat die toehoorders oproep tot die antwoord van geloof en belydenis.

Die reformasie het hom besig gehou met die hoogsbelangrike saak naamlik om nie die waarheid agter die teks te soek nie, maar om te luister na wat die konkrete teks as God se Woord aan ons wil sê..$^{10}$ ) Die Woord van God is nie 'n philosophia perennis met abstrakte en tydlose waarhede wat algemzen to ganklik is nie. Dit is ' $n$ Woord wat as konkrete en eenmalige Woord, as die konkrete openbaring van God in die tyd tot ons kom. Hierdie Woord word gepreek - dit is nie aanleiding tot 'n redelike, sedelike of selfs religieuse toespraak nie. Die teks word verkondig - dit is nie ' $n$ idee wat aansluit by die situasie nie. Prediking is ontmoeting, konfrontasie wat die Woord; buite dié ontmoeting verval die verklaring tot 'n weergawe van 'n sisteem, norme en ideologieë. ${ }^{11}$ )

9) Dijk K. „De dienst der prediking," p. 57

10) Calvyn J." "Institutie" II, 5, 19.

11) Müller B. A. a.w., p. 154v. 


\section{b) Piëtisme.}

Hierdie rigting was 'n reaksie teen die ortodoksie en die kille formalisme van daardie tyd. Die ortodoksie het die Skrif vanuit 'n leersisteem uitgelê wat noodwendig meegebring het dat die waarheid van die leer en die Woord gelyk gestel is aan mekaar. Die Skrif is slegs in die prediking gebruik om tekste te bekom wat as bewysplekke moes dien vir dogmatiese loci. Sodoende is die teologie verskraal en was daar van ware eksegese byna geen sprake. Die ortodoksie in Duitsland het geleidelik verstar tot 'n onbuigname dogmatiese interpretasie van die Heilige Skrif wat van die lidmaat slegs intelluktuele instemming met die sisteem gevra het.

Die piëtisme wat as 'n reaksieverskynsel navore kom, is ' $n$ breuk met hierdie tendense en verteenwoordig die beklemtoning van die gevoel en belewing van die godsdiens. Vir die Duitse piëtisme is die figuur van Spener van belang. Hy het hom veral op kategetese onderrig toege!ê en het 'n begin gemaak met die hou van privaat samekomste waar die lees van die Bybel, gemeenskaplike gebed en die bespreking van die Sondag se preek aan die orde was. Die doel van hierdie byeenkomste was om die geestelike lewe van die enkeling te verbreed en te verdiep.

Spener het telkens die teologiese twiste van sy tyd veroordeel en het gevra dat die opleiding van predikante prakties gerig moes wees. Die prediking van die kerk moes volgens hom, daarop gerig wees om die lidmate ten opsigte van hulle geloof en lewe te lei en dit moet nie 'n uitstalling wees van dis geleerdheid van die predikant nie. Spener het 'n terugkeer na die Skrifwaarhede beoog. ${ }^{12}$ )

Die resultaat van Spener se standpunt was wel 'n resultaat dat die Skrif weer geleer en geken is, dat die teologiese opleiding verbeter het, maar terselfdertyd het hy met sy stryd teen die dogmatisme beslis die gesag van die bəlydenisgeskrifte ondergrawe.

Die piëtisme het nie die lyn van die Reformasie gehou nie. Dit het geen oog gehad vir die amptelike karakter van die diens van die Woord nie. Die swaartekrag is van die objektiwiteit van die Woord verlê na die subjektiwiteit van die prediker. Daar is veel eerder verwys na die mens, sy lotgevalle en ervaring as na God en sy werk in Christus Jesus. Sodoende het die piëtisme die formele eise vir goeie prediking verwaarloos. ${ }^{13}$ )

12) Pont A. D. Diktaatlesings 1965

u) Dijk K. a.w., p. 59 . 
In die piëtistiese vroomheidsprediking word die explicatio begrens tot die aantoning van die objektiewe heilswaarhede van die Skrif. Dikwels word dit op onwetenskaplike wyse in die teks ingedra en daarna weer daaruit gehaal. Die groot klem val op applicatio deur die Gees wat verbind word met die toeëiening van die mens. Hierdie prediking is nie soseer teksprediking nie, maar die prediking van 'n Geesvervulde mens wat van die innerlike verligting deur die Gees getuig. Hier dra die mens die bron van die prediking in homself. Waar die Gees en die innerlike verligting ontbreek word die prediking 'n dorre saak en onmagtig om tot die geloof te lei. Die prediker probeer hierdie werking aanhelp deur op verskillende maniere op die givoel en die wil van die hoorder in te werk en aan te dring op geloofsbeslissings. ${ }^{\text {is }}$ )

c) Metodisme.

Gevra na 'n samevattende sruktuuranalise van die metodisme kan gemeld word dat die metodisme navore gekom het as 'n verset teen die verstarde vorms van die kerk as instituut. Hierdie opstand teen die verstarde institutêre kerk wil die persoonlike eksistensiële van die geloof in die middelpunt plaas. Wat die metode van bekering betref, word eers gevra na die kind van - God - bewussyn by die mens en daarna word gevra na die persoonlike beslissing wat duidelik aanwysbaar moet wees. Daar word gewys op die dringende noodsaak van die bislissing en daarom word die mens gestel voor die uiterste grense naamlik dood, hel, wederkoms. Vandaar dat iemand die metodisme eenmaal gekarakteriseer het as religieuse terrorisme.

'n Wesenlike beswaar teen die metodisme is dat die objektiewe totaal verlore gaan. Die hele teologie word vervlak. Die Christologie word so vervlak dat slegs 'n subjektief romantiese Jesus wat soos ons is, oorbly. ${ }^{13}$ ). Pneumatologies word die Heilige Gees losgemaak van die objektiewe heilsgebeure en daarom van die gesproke en geskrewe Woord van God. Die Skrif en Christus kan hoogstens as voorbeelde in die prediking dien, terwyl die mensedaad van heiligmaking die Godsdaad heeltemal verdring.

\section{RIGTINGS IN DIE HERMENEUTIEK.}

\section{R. Bultmann.}

Alvorens daar gepoog word om die hermeneutiese gang by Bultmann na te speur, moet ons eers die aandag wy aan die gang van sake by mense soos Schleiermacher, Dilthey en Heidegger. Dit was die filosoof Martin Heidegger wat die hermeneutiek beskou het as die ondersoek na die voorwaardes van

14) Müller B. A. a.w., p. 155v.

15) Pont A. D. aangehaal. 
die verstaan. Hoe is verstaan moontlik? Dilthey het die verskynsel van verstaan aan 'n diepgaande studie onderwerp. Volgens hom is die taal die enigste objektiewe uitdrukking van dit wat ten diepste in die mens leef. Dit was Dilthey wat tot die slotsom geraak het dat "Verstehen" gepaal word deur die subjek wat wil verstaan.

Schleiermacher het besef dat teksuitleg nie bloot meganies kan plaasvind nie. As hermeneutiese reël stel hy dan ook sy sogenaamde „Kongenialitâtslehre" wat vereis dat die eksegeet, om tot behoorlike verstaan (Verstehen) van die teks te kom, homself volkome moet inleef in die skrywer se denke. ${ }^{16}$ ) Hieruit blyk dat dit vir die eksegeet belangrik is om iets te verstaan van menswees - om jouself te verstaan en die mense rondom jou. Dit was Schleiermacher wat 'n radikale verandering in die Woorddiens teweeg gebring het, wat as teologiese uitgangspunt geneem het dat die essensie van die godsdiens nie geleë is in die ken nie, maar in die gevoel. Hy stel dat die mens homself afhanklik van God moet voel, dat die mens die gemeenskap met God moet ervaar. Die nadruk het vir hom geval, nie op die hoor wat God tot ons spreek in sy Woord nie, maar wel op die aanbidding van aie gelowiges en die tot uiting bring van dit wat daar in hulle bewussyn leef. „De preek is dan ook de „Daarstellung des religiösen Bewusstseins der Gemeinde” en de Schrift doen alleen dienst in zover zij ons leert, welke de rechte beleving is geweest bij de vromen van de oude dag en met name in de aanvangen van het Christendom". ${ }^{17}$ )

Vinet het die prediking meer beskou as ' $n$ middel om die gemeente tot heiligmaking op te voed, om die geestelik sedelike peil te verstewig. Hy het gestel dat die prediker in die prediking tog ook put uit sy eie ervaring, dat die lewensvolheid van die Heilige Gees moet bruis „en daarom mag, aan de preek nie altijd de noodsaak van een tekst gesteld worden". ${ }^{18}$ )

Vervolgens wil ons in breë trekke $\mathrm{R}$. Bultmann van nader besien. Bultmann het met die vraag geworstel hoe die boodskap van die Nuwe Testament vir die moderne mens bevatlik gemaak kan word. Vir Bultmann is die sentrale probleem in die teologie die situasie dat die Nuwe Testament deurtrek is met mites en derhalwe vir die mens van ons tyd beslis onaanvaarbaar. ${ }^{19}$ ) So het hy die taak van die teologie gesien om die suiwer oorspronklike evangeliese boodskap, in sy nog ongeskonde vorm, uit te wikkel uit sy mitiese omkleding. So 'n werksaamheid noem hy „Entmythologisierung."

16) Achtemeier "An introduction to the New Hermeneutic," p. 21.

1.7) Dijk K. a.W., p. 63.

18) Dijk K. a.w., p. 64

19) Koekemoer P. J. T. „Hervormde Teologiese studies”, jaargang 21 afl. 1 p. 18. 
Verder was Bultmann van mening dat 'n Bybelse voorstelling nie bloot op gesigswaarde beoordeel kan word nie, maar daar moet eers gevra word na die belewenis van die Bybelskrywer wat hierdie mite tot gevolg het. Die beslissende vraag by die verklaar en uitlê van die Bybelwoord kom dan hierop neer: hoe word die menslike eksistensie in die Bybel verstaan? ${ }^{20}$ )

Bultmann het die mens altyd gesien as iemand wat in 'n bepaalde relasie tot homself staan, dit is wat 'n ,Selbstverständnis' besit. Hierdie ,Selbverständnis' wat die mens steeds van homself het, ontsluit die moontlikheid vir die verstaan van die Woord van God. Bultmann stel dat ek die teks slegs kan verstaan soverre die teks my in my menswees raak. Die verbinding tussen my en die Bybelskrywer is die groot vrae wat opgeroep word na my menslike bestaan.

Wanneer 'n bepaalde teks uitgelê word, dan gaan dit by Bultmann om die interpretasie. Hierdie interpretasie was dan gelei deur ' $n$ voorlopige verstaan van die menslike bestaan. Aan die grond van die Skrifteks lê 'n verstaan van die bestaan waarvan die hoor 'n eksistensiële voorkennis besit. Nou kom hierdie saak, hierdie Skrifteks in geobjektiveerde, verduisterde taal tot ons. Die teks is in werklikheid die neerslag van 'n eksistensiële beslissing in die verlede. Ons moet dus agter die taal weer by die beslissing uitkom. Die teks moet die uitlegger dus teruglei en hom weer voor die beslissing plaas.

Bultmann het gesoek na die regte vraagstelling waaronder die Nuwe Testament reg verstaan en aktueel verklaar kan word. Hy wil in die eksistensiële interpretasie getrou bly aan beide teks en die moderne mens. ${ }^{21}$ )

Ons gaan nie die hermeneutiese beginsels van Bultmann kommentarieer en beoordeel nie, dit is 'n studie op homself, maar ons wil net meld dat die homilitiek nie kan bekostig om die probleemstelling van Bultmann tersyde te skuif as 'n diskussie op die teoretiese of filosofiese vlak nie. Sy probleemstelling raak die hart van die prediking: die vraag van die verstaanbaarheid en verstaansmoontlikheid van die Skrifverklaring. Dit is 'n worsteling om die aktualiteit van die kerugma, om die inhoud van die Skrif so in die situasie in te verklaar dat dit die mens in sy volle bestaan raak. $^{22}$ )

Die groot verdienste van Bultmann vir die homilitiek en gepaard daarmee vir die hemeneutiek, is dat hy na die vraagstelling gesoek het waaronder die Skrif in die prediking reg verstaan en eksistensieel gehoor kan word.

20) De Jonge Theologie als hermeneutiek artikel p. 76

21) Muller B. A. a.w., p. 164.

22) Müller B. A a.w., p. 171. 
Wat sy hemeneutiese beginsels betref, volstaan ons met die volgende stelling van Müller $^{23}$ )

1. Die hermeneutiese prinsiep van Bultmann verkrag die sprekende dinamiek van die lewende Woord.

2. Die hermeneutiese prinsiep van Bultmann is ontoelaatbaar omdat dit die inhoud en die sentrale motief van die Skrif verskraal.

3. Die hermeneutiese prinsiep van Bultmann is ongenoegsaam om die appél van die aktuele Woord in die hede uit te druk.

\section{HOMILETIESE EKSEGESE.}

Voordat ons die aandag op die homiletiese eksegese toespits, gaan ons verskillende metodes van Skrifuitleg stipuleer om enigsins 'n agtergrond te skep.

Eerstens noem ons die literêr-historiese metode, ook ginoem die histories-filologiese metode. Hierdie metode is ingestel op die woordelike en historiese sin van die teks. Dit gaan in op al die vrae rondom die vorm, die oorlewering, die redaksiegeskiedenis ens. Hierdie metode is broodnodig vir ware uitleg. Hierdie metode bied die vaste riglyne waarlangs die eksegeet noodwendigerwys moet vra na woordbetekenisse, na die historiese verband na teks- en tydsomstandighede.

Wanneer ons die allegoriese metode onder oë neem, mag bloot net opgemerk word dat dit hier weinig gaan om 'n wetenskaplike verklaring van die Skrif. Die allegoriese metode is nie ingestel op die uitleg van die teks of perikoop nie, maar die verklaarder lees daarin en voeg daaraan toe wat hy graag wil. Daarom is die sogenaamde allegoriese metode, wat met die letterlike betekenis van die teks ontevrede is en dit vervang met 'n sogenaamde diepere betekenis of geestelike betekenis, niks anders as ' $n$ vergrype van die Skrif self nie. Sy skrywers word die swye opgelê ter wille van die monoloog van die eksegeet. ${ }^{24}$ )

Wat die tipologiese metode betref, wens ons slegs aan te stip dat dit verskil van die allegorie. Die tipologie hou hom streng aan geskiedkundige gebeure. Dit sien in die geskiedkundige gebeure ' $n$ afkondiging van die heenverwysing na die heilsgebeure van die nuwe tyd deur God self.

Wanneer ons die tipologie moet beoordeel, wens ons slegs op te merk dat die blote feit dat tipologie in die Nuwe Testament voorkom, dit nog geen argument is om dit as 'n toelaatbare metode in die wetenskaplike eksegese te ag nie.

23) Müller B. A. a.w., p. 179, 181, 186.

24) Mans C. J. „Van der Hoff - jaarblad” 1971, p. 17. 
Die tipologie kan wel 'n dienende rol speel by ons uitleg van die $\mathrm{Ou}$ Testament, maar dan moet ons onthou om dieselfde ,tipologiese visie' te hé as die skrywers van die Nuwe Testament, naamlik om te onthou dat die God wat in die Ou Testament handelend optree dieselfde God is wat in die Nuwe Testament handel. Daar moet uiters versigtig opgetree word met hierdie metode, om nie te wil poog om Christus op allerlei wyse in die Ou Testament in te lees' en ,terug te vind' nie. ${ }^{25}$ )

Dit was Rasker ${ }^{20}$ ) wat die begrip homilitiese eksegese gebruik en uitgebou het. Sy bedoeling daarmee was dat die eksegeet se oog en oor ook gerig moes wees tot diegene wat na die gepredikte Woord luister. As Rasker wil dat die prediker by sy voorbereiding van die preek die gemeente en sy bepaalde situasie in berekening moet bring, is dit heeltemal in orde. ${ }^{27}$ ) Joh. de Groot ${ }^{25}$ ) skryf dat ,elke exegese die niet verder gaat dan wat grammatica en historisch-kritische toelichting vermogen te zeggen, is mager en onvruchtbaar."

Uit wat tot nou toe gesê is, blyk dit dat die funksie van die uitleg van 'n preek is om die rykdom vir die gemeente bloot te lê. Prof. de $\mathrm{Wet}^{29}$ ) stel dat om hierdie stelling reg te verstaan dit nodig is om te onderskei tussen akademiese en 'n homiletiese eksegese. „Met akademiese eksegese word die filologies histories - kritiese ontleding van die teks bedoel of te wel die studeerkamerwerk van die predikant. Dit is daardie deel van die predikant se werk wat nooit uitgestel kan word nie, maar wanneer dit nagelaat word, dan is die preek soos 'n liggaam sonder siel of soos 'n boodskapper wat sy boodskap langs die pad vergeet het.

Die homiletiese eksegese is die omskrywende analise of die vertaling van die teks in die taal van die kerkvolk wat eers dan moontlik is as dit gedra word deur die filologies-historieskritiese ondersoek van die teks. Die homiletiese eksegese is eintlik niks anders as die afhaal van die omhulsels waarin die rykdom van die teks wat ontdek is met die akademiese eksegese vir die doeleindes van die oorbrenging aan die gemeente toegewikkel was nie."

Met die tot-spreke-bring van die teks aan die gemeente wat in erediens vergader is, moet wel deeglik rekening gehou word ook met die hoorders. Die eksegeet moet nie doof en blind wees vir die situasie waarin die gemeente bevange is nie. Maar

25) Breytenbach A. P. B. „Hervormde Teologiese Studies,” jaargang 28 afl. 1 , p. 21.

26) Rasker, Homiletischen Richtlijnen III, Postille 1961-1962, p. 17.

27) Du Toit H. D. A. artikel in "Hermeneutica," p. 212.

28) de Groot Joh. „Exegese en Preek,” p. 8.

29) De Wet J. I. aangehaal. 
dan moet die probleme en vrae nie so aan die teks opgedring word om die teks daardeur toepaslik te maak nie. Nooit mag die predikant se insigte in die nood en vrae van die tyd die maatstaf van die prediking wees nie. Die gevaar is dan wesenlik dat die mens se eise bepalend word by die eksegese (Bultmann, Bonhoeffer). Die eise van die mens kan dan so rigtinggewend van aard word dat die eksegeet hom in die prediking sal moet laat lei deur dit wat die moderne mens sal aanvaar en wat hy sal verwerp. Sodoende sal die situasie so 'n bepalende faktor word dat nie net 'n ontmithologiserende Bybel oorbly nie, maar 'n skewe, verdraaide, onegte beeld van die evangelie.

Homiletiese eksegese is reg en noodsaaklik as dit gesien word in die lig van Barth en Rasker wat wil dat die predikant sy gemeente in gedagte moet hou wanneer hy sy preek voorberei. Ons wys egter homiletiese eksegese ten strengste af wanneer die toepassing en die situasie in die teks ingedra word en daardeur tot onjuiste uitleg, of liewers inleg lei. ${ }^{30}$ )

\section{ALGEMENE OPMERKINGS.}

Die antwoord op die vraag hoe die Skrif uitgelê moet word in die prediking sal bevredigend beantwoord word as daar 'n antwoord op hierdie vraag gevind kan word: hoe moet die teks of perikoop uitgelê word dat die oorspronklike bedoeling van die Heilige Gees tot uitdrukking kom? Genoemde twee vrae hou so 'n noue verband dat dit een en dieselfde vraagstelliing is.

Die prediker durf nie sondermeer 'n teks neem, dit verklaar soos dit hom behaag en toepas soos dit aan hom welgevallig is nie. Daar mag geen plek gegun word aan willekeurige verklaring nie; „want geen profesie van die Skrif is 'n saak van eie uitlegging nie; ,want geen profesie is ooit deur die wil van 'n mens voortgebring nie, maar deur die Heilige Gees gedrywe, het die heilige mense van God gespreek." (II Petr. 1:21)

Daarom moet die uitlegger 'n beskeie, geduldige, gelowige en biddende luisteraar wees wat met al die hulpmiddels tot sy beskikking geboë is oor die teks van die skrywer vir wie hy wil hoor' omdat hy God en nie sy eie stem wil hoor nie. Dit kan nooit gaan om wat ons in die humanistiese of sosialistiese dampkringe van ons eeu daarin geskrywe wil sien staan nie. Dit moet gaan om dit wat daar geskrywe is. ${ }^{31}$ ) Daardeur wil God ons aanspreek. Paulus het reeds die aandag van sy lesers daarop gevestig: „... ons skryf aan julle niks anders as wat julle lees of ook verstaan nie." (II Kor. 1:13).

30) Du Toit - artikel in „Hermeneutica”, p. 218.

31) Mans C. J. aangehaal p. 16. 
As 'n bepaalde teks tot spreke gebring moet word, sal dit beteken dat die prediker moet vasstel wat die oorspronklike bedoeling was van die outeur, gedryf deur die Heilige Gees, toe hy hierdie bepaalde teks geskryf het. Die predikant sal die oorspronklike teks moet neem en daaruit die oorspronklike gedagte moet vind van dit wat die skrywer oorspronklik bedoel het. Die kultuuragtergrond van die skrywer en die kultuursituasie van die mense tot wie dit gerig is, sal die aandag nie mag ontsnap nie. Nooit mag dit vergeet word dat die bepaalde teks in ' $n$ bepaalde hoofstuk, Bybelboek en in verband met die hele Bybel as sodanig staan nie. ${ }^{32}$ ) Eers wanneer die prediker langs hierdie weg die oorspronklike bedoeling van die teks vasgestel het, kan dit tot spreke gebring word in die bepaalde gemeente waarin die prediker staan met inagneming die feit dat hierdie verkondiging van hom ook plaasvind op 'n bepaalde plek en tyd, gerig tot mense wat leef in bepaalde lewensomstandighede. ${ }^{33}$ )

Die werklike verklaring luister na die Woord, vanuit die bestaan en die situasie en verklaar die Woord al luisterend in die bestaan in. Daarom is verklaring alles behalwe tydloos en abstrak, maar eerder tydsverbonde. ${ }^{34}$ ) In die prediking ontmoet die gestalte van cie Woord die gestalte van die gemeente in die tyd. Die aktualiteit en die vrae van die tyd kry werklik diepte vanuit die aktuele Woord wat in sy woordstruktuur die hede binnetree. ${ }^{35}$ )

Daarom is die verklaring in die prediking geen rasionele, religieus-sedelike of antropologiese uiteensetting van die Skrifwaarhede nie. Die verklaring is nie maar die ontbloting van 'n sisteem van algemene en tydlose waarhede ie. Dit is nie ' $n$ intellektuele, antropologiese bekendmaking en ontrafeling van die anders duistere strukture van die Woord nie. Die Woord wys op die gebeure van die ontmoeting wat gekonsentreer word in Jesus Christus „God . . geopenbaar in die vlees.” (I Tim. 3:16) Alle verklaring is verklaring van hierdie lewende Woord van God wat die mens deur die werking van die Gees tot 'n lewende ontmoeting met God self in Jesus Christus wil lei. ${ }^{36}$ )

Die Skrif is dikwels moeilik om te verstaan. (II Petr. 3:16) Dit is God se Woord wat in sy diepe geheimenis en onuitputlikheid teenoor alle oppervlakkigheid staan. Ons staan nie alleen voor vreemde woorde, uitdrukkinge ens. nie, maar ook voor moeilike tekste en gedeeltes wat hulle inhoud betref. Daarom

32) Beukes M. J. du P. artikel in „Van der Hoff - jaarblad” 1968, p. 19.

33) Beukes M. J. u P. aangehaal p. 19.

34) Weber 0 . „Gottesdienst”, p. 114.

35) Müller B. A. a.w. p. 201.'

s6) Müller B. A. a.w. p. 198. 
is studie, eksegese en verklaring nodig. Ons moet telkens maar weer met hierdie Skrif waarin daar nooit van vlakke helderheid sprake is nie, in gesprek tree en ons daarvoor oopsluit. ${ }^{37}$ ) God openbaar Hom in sy Woord en aan hierdie Woord bly Hy getrou. As die sprekende en selfverklarende Woord tree dit ons tegemoet. Dit wil verklaarbaar, verstaanbaar en duidelik in die situasie van die eksistensiële ontmoeting wees. ${ }^{38}$ )

Ons sluit af met die Reformatoriese beginsel Scriptura sui ipsius interpres, dat die Bybe! die beste deur die Bybel verklaar word. As hieraan vasgeklem word en eksegese sy duidelike beslag kry, sal dit verantwoorde prediking wees met die diepe besef dat geen professie 'n saak van eie uitlegging is nie.

37) Müler B. A. a.w. p. 202.

38) Barth K., K.D., IV/3/2 p. 973 